\title{
RETELLING STRATEGY TOWARDS STUDENTS' ENGLISH READING COMPREHENSION AT SENIOR HIGH SCHOOLS
}

\author{
${ }^{1}$ Rudiawan \& ${ }^{2}$ Jupri \\ ${ }^{1}$ English Teacher of SMAN 1 Jonggat, Central Lombok, Indonesia \\ ${ }^{2}$ English lecturer, Mandalika University of Education, Indonesia \\ Corresponding Email Author: rudiawan@gmail.com
}

\begin{tabular}{l}
\hline \hline Article Info \\
\hline Article History \\
Received: September 2020 \\
Revised: October 2020 \\
Published: October 2020 \\
\hline Keywords \\
Retelling Strategy; \\
Reading Comprehension;
\end{tabular}

\begin{abstract}
It was found that the majority of the students felt reluctant, nervous, and shy to read, especially when they were asked to read in front of their friends. The research objective is to find out how the use of the retelling-based instruction strategy can increase the students' reading comprehension and find out the participants' perceptions on the Retelling as a technique used to improve their reading comprehension. This research was experimental research that deals with utilizing the independent variable (the retelling technique) toward learners' reading comprehension. Fifty-two students were involved in this study. The XI-A class was taken as the experimental class, and XI-B was treated as the control class. The research shows that it is significantly different in teaching English by using a retelling strategy to improve the students' reading comprehension. The sig. (2-tailed) is 0.000 is lower than the significant level $(0.05)$. Thus, the retelling strategy can improve the students' reading comprehension in SMAN 1 Jonggat, Praya, Central Lombok. The t-test is higher than the t-table, $8.04<1.67$. This also certainly concludes that there is a significant difference in teaching reading by using retelling strategy and not using retelling strategy. There is a positive contribution to the teaching of English reading comprehension by using retelling strategy in the SMAN 1 Jonngat, Praya, Central Lombok. All 25 students in the experimental class were happy and enjoyed reading by using the retelling strategy.
\end{abstract}

How to cite: Rudiawan \& Jupri. (2020). Retelling strategy towards students' English reading comprehension at senior high schools. JOLLT Journal of Languages and Language Teaching, 8(4), 432-441. DOI: https://doi.org/10.33394/jollt.v8i4.2815

\section{INTRODUCTION}

Recently, English has been increasingly becoming the medium of communication in every aspect of life, particularly in the education domain. As a result, many people learn English as an endeavor to face global demand. The principal purpose for them in knowing it is to be able to read. They consider that reading is the most crucial language skill, among other skills. According to research findings, reading seems intuitively the most important: people who know a language are referred to as readers of that language. Many, if not most, foreign language learners are primarily interested in learning to read.

In Indonesia, English is a foreign language (Widiati \& Cahyono, 2006: 276). For Indonesian people, English is learned after they mastered their first language. Gebhard (1998) states that English as a foreign language means that English is studied by people who live in places where English is not their first language; English is only taught as a school subject. For this position, many Indonesian people, including students, find several problems in mastering it. They consider that English is quite difficult to learn and even think it is the most difficult one to master. 
Various factors may trigger the difficulties in mastering English as a foreign language. Those could be from the English language itself, or from the learners themselves, or possibly from the learning process itself. Obviously, the teacher's role also plays a crucial effect (Nunan, 1999: 93). English is a complex language for Indonesian people because it contains various patterns, unique spelling, and pronunciation. It is said that English is badly spelled (Literary-research, 2001).

Based on the researcher's experience teaching in this school, the researcher found that one of the problems that restrain their reading ability is lack of self-confidence. It was based on the researcher's teaching experience. It was found that the majority of the students still felt reluctant, nervous, and shy to read, especially when they were asked to read in front of their friends. Knowing that they are heterogeneous, coming from different characters, the background of education, and families. It seemed that they seldom cooperate. This condition also affected their active involvement during their English class. Some students have willing to ask for clarification from their teacher. They responded to or answered the teacher's instruction and question, did the task given by having an active discussion with their peer/group, helped or asked for help from each other, and actively answered their friends' questions. It was found that out of 26 students, there were only 7 students (27\%) who were categorized as active students.

A large body of reading research has recently targeted strategy instruction, which presumes that learners who are empowered with knowledge of a particular reading strategy, and specifically how it is used, can better increase their reading comprehension (Anderson, 2005; Beers, 2000). Moreover, Pressley (2002) emphasized that reading education should focus on comprehension instruction: readers should be taught comprehension strategies. Comprehension instruction entails "teaching people how to construct meaning from text rather than simply finding the meaning put there by the author" (Pressley, 2002: 390). In order to comprehend the text well, the student has to be engaged in utilizing strategies "to construct meaning from text, using text information to build conceptual understanding, [and] effectively communicating ideas orally and in writing" (Gambrell, Malloy, \& Mazzoni, 2007, p. 13). Students who engage in such meaningful literacy activities can become motivated and achieve reading success.

In the context of second language (L2) learning, the teacher can implement best practices in relevant and meaningful ways when teaching students to read English as a foreign language (EFL). Reading comprehension strategies for EFL learners should promote memorizing linguistic symbols and understand ideas in the text. In an EFL classroom, the following responses are quite common. When teaching students to read an English article, a language instructor may ask them to describe what they have read once they have finished reading. In many situations, the instructor repeatedly encounters students' silent responses or replies, such as, "Sorry, I have nothing to tell you," "I don't remember," or "I have no idea about that." These responses reveal the problem: EFL learners cannot remember anything after they read a piece of English text. To overcome this problem, an instructor should offer students a strategy to reconstruct meaning in order to help them remember and understand the information in the text. One strategy that engages students in reconstruction is Retelling. The retelling technique is a verbal rehearsal skill in which readers restate what they have read. Through retelling the text, learners can engage in meaning reconstruction by generalizing text information, connecting details, and referring to prior personal knowledge.

In English-speaking contexts, Retelling has been used as an instructional tool for quite a long time. Some research on the effects of retelling-based reading programs shows that Retelling is an effective tool used to improve students' text comprehension in a holistic fashion and to enhance students' ability to recall entire texts (Cullinan, Harwood, \& Galad, 1983; French, 1988; Gambrell, Koskinen, \& Kapinus, 1991; Morrow, 1985, 1986, 1993; 
Moss, 1997, 2003, 2004). However, in the context of learning English as a second or foreign language (ESL/EFL), no studies in the literature on Retelling examine it as an instructional tool for increasing reading comprehension. Thus, the present study instructed Chinese adult learners in the retelling technique and examined the effects of Retelling on their reading comprehension performance. The present study can contribute to the current body of knowledge about how to improve comprehension in ESL/EFL reading education.

Despite the wide use of the retelling technique in education and the amount of research examining its effects on comprehension in a native English-speaking context, the above literature review exposed several gaps. First, there are few studies on the effects of the retelling technique on ESL/EFL learning. Using recall as a reading comprehension assessment tool, Bernhardt (1991) recommended that the analysis of students' retelling protocol be an instructional device to improve FL learners' reading comprehension. More recently, Moss (2004) indicates that English-language learners benefited from text retelling. A second gap in the literature is that, despite the documented robust effect of Retelling on improving native speakers' comprehension, the linguistic aspect of reading comprehension that is best improved by Retelling has not yet been deeply investigated. Through the questionnaire employed in the present study, the researcher examined the impact of retelling with regard to the participants' understanding at the word-level, sentence-level, and text-level. Third, the text type utilized in previous research has been either expository or narrative. But these two text types have different structures that may spark readers to activate diverse strategies for comprehension. In fact, a reader may be involved in both types of article reading in daily life. Therefore, to provide a complete reading comprehension performance analysis, the researcher used both narrative and expository texts. Fourth, the participants in previous research have been kindergarten, elementary, and high school students. I assumed that the retelling technique that worked with kindergarten, elementary, and secondary students, would also serve other students, namely post-secondary students. Thus, the present study examined university students.

Most importantly, the during-reading phase has been ignored in the previous research using Retelling as an instructional tool to activate the learners' reading comprehension. Previous research has used the retelling technique only as a follow-up strategy. As a result, these studies on the effects of Retelling only examined reading comprehension following reading or listening. However, what students comprehend and how they understand the text during reading may influence what they retell after reading. Therefore, the present study asked participants to use Retelling and examined how they understood the text during reading. The purpose of this study was to examine the effects of the retelling technique on ESL learners' reading comprehension of expository and narrative texts.

\section{RESEARCH METHOD}

The design of this research was experimental research. This design deals with utilizing the independent variable (the retelling technique) toward learners' reading comprehension. The research step was started from the problem identification found by the teacher in his classroom. Latief (2009) states that experimental research for English learning aims to develop and apply a certain instructional strategy to solve practical instructional problems in English classroom teaching. This research was designed to apply the retelling strategy to solve the problem in the English class of the XI grade students of SMAN 1 Jonggat, Central Lombok, West Nusa Tenggara.

In conducting this experimental research, the researcher collaborated with one collaborator. The collaborator was the teacher who taught English in this school. It is based on the early agreement; the researcher acts as a teacher implementing the retelling strategy. The collaborator helps the researcher observe the teaching process by filling the supporting 
instrument to gain the supporting data. Before conducting the research, the collaborator is trained on how to use the research instruments such as observation checklists and field notes. The collaborator, who is equipped with those research instruments, observes the researcher and students in the teaching and learning activities during the retelling strategy implementation.

\section{Research Design}

The experimental research design used in this study is an experimental process adapted from the model proposed by Kemmis and McTaggart (cited in Koshy 2007). It consists of five main steps: problem identification, implementing the treatment, distributing the instruments, gaining the data and analyzing the data.

\section{Population and Sample}

This study was conducted at state senior high school or SMAN1 Jonggat, which is located in Jl. Jurusan Praya, Central Lombok, West Nusa Tenggara Province. The research population was 52 students of XI Grade of SMAN1 Jonggat, Central Lombok, West Nusa Tenggara, in 2019/2020. The XI grade students were divided into two classes, XI-A and XIB. Class of XI-A contained 25 students, and XI-B contained 27 students. The XI-A class was taken as the experimental class, and XI-B was treated as the control class, controlling the experimental class, which was treated by implementing the retelling strategy.

The researchers utilize non-random sampling as the sampling of the research. It was conducted for the XI grade of SMAN1 Jonggat only had two classes, which were not possible to be randomized. This was done to maintain the intake setting of the class. The researchers also have consulted with experts who provided some suggestions not to randomize the research participants.

\section{Instruments}

Reading comprehension was tested in the pre- and post-tests. The pre- and post-tests are group tests featuring the same text, which measures the participant's ability to comprehend reading comprehension in English. The participants read five passages and answer 25 questions. These passages and questions are directly adopted from Pauk (2000). In the original format, each passage is followed by six types of questions: main idea, subject matter, supporting details, conclusions, clarifying devices, and vocabulary in context. The main idea question is taken away because it is not the multiple-choice variety from which participants select one correct option.

The rationale for using the same test for both pre- and post-measurement is to assure objectively comparable tests, thus avoiding the problem of equating different formats of preand post-tests. The six-week interval between administrations is considered long enough to control for any short-term memory effects. This is because the participants are not provided with the correct answers after the pre-test, so they have no way of knowing whether their answer is correct; moreover, they are unlikely to remember how they have answered a question the first time. Thus, the interval is deemed long enough to control any significant learning except for the training.

The questionnaire of self-evaluation results. The questionnaire contained 5 items with a 0 and 5 Likert Scale for each item $(0=$ strongly disagree, $5=$ strongly agree $)$. The questionnaire includes: (1) some statements pertaining to the impact of Retelling after reading, (2) some statements of the impact of the ability to tell after reading, (3) some statements about the impact of enjoying the activity of reading, (4) some statements of the impact of the ability of writing after reading, and (5) some statements on the impact of the ability to gain vocabulary after reading. 
Individual items dealing with the periods during and after reading are further divided into word-level, sentence-level, content details, and the text's overall meaning. In addition, two items covering the period during reading focus on the participants' affective factors, exploring how participants conceive Retelling as a strategy that helps them pay attention to the reading material. Questionnaires are written in English and translated into Bahasa Indonesia. Participants complete the Bahasa Indonesia version. In addition, the self-report focuses on the participant's experience with Retelling. It contains one semi-open question asking whether the participants want to continue to use the retelling technique after the program is over and why or why not

\section{Data Analysis}

After data collection, the researcher applies Statistic Package for Social Science for Windows (SPSS) version 22.0 to compute the data collected from reading comprehension pre- and post-tests, the participants' reading performance questionnaire. The researcher conducts the independent samples t-tests to investigate whether there are differences between the experimental and control groups on reading comprehension tests and during- and after reading performance. Furthermore, self-reports are analyzed qualitatively. The analysis is focused on why the students feel meaningful learning to improve their reading comprehension or why not. The qualitative analysis is used as supplementary data to help interpret the results of the statistical analysis.

\section{RESEARCH FINDINGS AND DISCUSSION Research Findings}

The result's presentation was intended to find out the answer to the problem of investigation as formulated in the introduction. To find out the problem's solution, the researcher intended to analyze the data obtained from the students' test results. The data analysis was meant to determine the implementation of the retelling technique in increasing students' reading comprehension at the grade of XI A and B of SMAN 1 Jonggat in the academic year 2019/2020. In this step, a finishing formula from a t-test analysis of SPSS computation has been adopted to determine the significant difference between the teaching of reading comprehension by using retelling strategy and the teaching of reading comprehension using a non-retelling strategy.

In the first step of the research, the researcher came to the class and delivered a kind of pre-test to explore the students' reading ability. A simple reading test was delivered to students. Some of the students were familiar with the topics discussed, but others seem so strange and even confused when the researcher tried to examine them with the reading test. To mark the students' test results, the researcher gave six points for the lowest score, then the highest possible score is nine.

Secondly, after the pre-test was administered, the researcher held out the regular treatment of the teaching of reading comprehension by using retelling strategy to the experimental class and non-retelling strategy for the control class. The number of students taken as the population of this study was 52 students. Twenty-five students were treated for the experimental group, and 27 others were treated as the control group. They had been chosen in non-randomization. This was applied due to maintaining the intake setting of the class. The researcher also has consulted with the observer, who provides some suggestions not to randomize the research participants.

The experimental group students were treated using the retelling strategy to improve the students' reading comprehension. Meanwhile, the students categorized into the control group were treated using non-retelling techniques or a conventional teaching method to teach 
reading comprehension. The treatments were conducted about eight meetings and the researcher came to the class (experimental and control groups) four times a month. The experimental group and the control group were treated with a post-test to know how well the students' major competence or individual reading comprehension ability.

In finding out the positive effect of the retelling technique in increasing the students' reading comprehension, the experimental and control groups' data are put in the tables and counted for the mean scores. This is to find out the comparison between both pre and post-test between both groups. In analyzing the data obtained, the researcher follows the following steps.

Arranging and putting the score of pre and post-tests between both experimental and control groups and analyzing the data using early statistical computation to measure the results of descriptive statistical computation in finding out the mean score of pre and posttests between experimental and control classes and analyzing the data by using a further statistical computation to measure the significance of teaching reading comprehension by using a specific teaching technique in the form of retelling strategy of teaching. This statistical analysis is called inferential statistical analysis, which was conducted to find out the effect of teaching reading comprehension by using the retelling strategy.

\section{Descriptive Statistical Analysis}

The next steps are analyzing the results of pre and post-tests between both experimental and control groups. The researcher applied computer software for analyzing the data. The statistical application is called SPSS Statistical Analysis Version 22 from IBM. The Results of Descriptive Statistical Analysis of Post Tests for both Experimental and Control Group.

Table 2

The Results Descriptive Statistical Analysis

\begin{tabular}{llllll}
\hline \multicolumn{5}{c}{ Group Statistics } \\
\hline \multirow{2}{*}{ Nilai } & Group & $\mathrm{N}$ & Mean & Std. Deviation & Std. Error Mean \\
\cline { 2 - 6 } & 1.00 & 25 & 85.1600 & 6.43998 & 1.28800 \\
\hline
\end{tabular}

Pursuant to the results of the descriptive statistical analysis above, the researcher can now look at the comparison of the mean scores between both experimental and control classes. The experimental group's mean score is higher than that of the control group, which is $85.16<72.11$. This surely indicates that the experimental group performs better in learning reading comprehension than the control group. The teaching of reading comprehension by using the retelling strategy is better than using a non-retelling strategy. The retelling technique is positively improving the students' reading comprehension. It is now answering the researcher's hypothesis derived from the research question that the retelling strategy is effective in improving the learners' reading comprehension in SMAN 1 Jonggat in the academic year of 2019/2020.

The researcher positively argues that teaching English reading by using retelling strategy can now be promoted. EFL teachers can surely adopt the results of this investigation to solve problems in EFL settings, particularly the teaching of English in middle school in non-English speaking countries. It was based on the above results of descriptive statistical analysis; the researcher can now conclude that the retelling technique is positively improving the students' reading comprehension in the level of middle school. 


\section{Inferential Statistical Analysis}

After the steps of analyzing the results of pre and post-tests in both experimental and control groups in the form of descriptive statistical analysis, the researcher can now proceed to further statistical analysis by using computer software of SPSS from IBM for analyzing the data. The further statistical application is similarly applied from SPSS Statistical Analysis Version 22 from IBM. This deeper analysis is called inferential statistical analysis, which certainly examines both the post-test results between experimental and control groups. The following tables show the results of inferential statistical computation from IBM SPSS Version 22.

Pursuant to the inferential statistical analysis results above, the researcher can now look at the comparison of the results of significant differences found after the computation of the analysis by using an independent sample t-test. The result of the sig. (2-tailed) shows .000, which is higher than that of the significant level of 0.05 which was set by the researcher, which is $0.000>0.05$. This indicates that the experimental group that was taught using the retelling technique performs better in learning reading comprehension than the control group. Reading comprehension in the practical class by using the retelling strategy shows better results than using a non-retelling strategy. The retelling technique is positively increasing the students' reading comprehension. It is now also further answering the researcher's hypothesis derived from the research question that the retelling strategy effectively improves the learners' reading comprehension in SMAN 1 Jonggat in the academic year of 2019/2020.

The inferential statistical analysis results show that it is significantly different in teaching English by using a retelling strategy to improve the students' reading comprehension. The results of the sig. (2-tailed) indicate 0.000 which lower than the significant level (0.05). Hence, it is now proven that reading comprehension in middle school, particularly in SMAN 1 Jonggat Praya, Central Lombok, can be assisted by using the retelling strategy. That is why EFL teachers can surely cope with this finding. English teachers in the level of middle schools can teach reading comprehension in English by using the retelling strategy. The researcher then looked at the result of the t-table, which is commonly stated in general in the list of the distribution of the t-table. The researcher found that the results of the $\mathrm{t}$-table is 1.67. The researcher then compared the results of the t-test and the results of the ttable. It was found that the t-test is 8.04 , and the results of the t-table is 1.67 . Therefore, the $t-$ test is higher than the t-table, $8.04<1.67$.

\section{Discussion}

The computation of the data analysis from the descriptive statistical analysis in the former pages shows that the two mean scores of the experimental and control groups are resulting in 85.16 for the experimental class and 72.11 for the control class. This figure that the experimental class shows a higher mean score than that of the control class. The experimental class, which was taught by using the retelling strategy, performed better results in acquiring reading comprehension. The researcher surely can conclude that based on the mean score results from descriptive statistical analysis, it was found that 85.16 for experimental group is higher than 72.11 for the control group. That is $85.16<72.11$. It means that the degree of difference between two mean scores is the significance for both classes in the teaching of reading by using and by not using the retelling strategy of teaching.

The result above indicates that the researcher's hypothesis during the promotion of the research questions can be accepted. Thus, the retelling technique is effective in increasing students' reading comprehension. From the result of the discussion above, it is clearly seen that the retelling technique is able to make the students understand the reading comprehension by their own. The importance in this activity, teachers should build-up and activate teaching strategy to the students right before reading activity. 
The results of the inferential statistical analysis also show that there is a significant difference in teaching English by using the retelling strategy in improving the students' reading comprehension. The results of the sig. (2-tailed) indicate 0.000 , which is lower than the significant level (0.05). That is why it was proven that reading comprehension in the level of middle school, particularly in SMAN 1 Jonggat Praya, Central Lombok, can be assisted by using retelling strategy. That is why EFL teachers can surely cope with this finding. English teachers in middle schools can teach reading comprehension in English by using the retelling strategy.

This finding indicates a corroboration to former research findings, which found that Retelling increases elementary students' reading comprehension in terms of both the quantity and quality of what is understood (Richardson \& Morgan, 2003; Tennessee Department of Education, 2007). Thus, this research finding positively supported the former research finding in the retelling strategy of English teaching.

These findings were in line with some research studies that have evaluated the impact of oral Retelling on students' last memories of a story, such as Dudukovic, Marsh \& Tversky, 2004; Marsh \& Tversky, 2004; Marsh, Tversky \& Huston, 2005; Tversky \& Marsh, 2000. The results indicate that Retelling has both positive and negative consequences for recall. Different kinds of rehearsal involving other purposes, audiences, and social contexts may differentially affect memory. Marsh (2007) stated that the re-tellers' different purposes could result in other recall consequences. It is because concepts formulated during Retelling affect later recall of the entire event (Marsh, Tversky \& Huston, 2005; Tversky \& Marsh, 2000).

\section{CONCLUSION}

The data analysis from the descriptive statistical analysis shows that the experimental group's mean scores are higher than the control group, resulting in $85.16<72.11$. This indicates that the experimental class, which was using the retelling strategy, performed better in acquiring reading comprehension. The researcher can conclude that based on the results of the mean score from descriptive statistical analysis, it indicated that the degree of difference between two mean scores is different for both classes in the teaching of reading by using and not using the retelling strategy of teaching. Thus, the retelling strategy can improve the students' reading comprehension in SMAN 1 Jonggat, Praya, Central Lombok. The inferential statistical analysis shows that it is significantly different in teaching English by using a retelling strategy to improve the students' reading comprehension. The sig. (2-tailed) is 0.000 is lower than the significant level (0.05). Thus, the retelling strategy can improve the students' reading comprehension in SMAN 1 Jonggat, Praya, Central Lombok.

The t-test is higher than the t-table, $8.04<1.67$. It also concludes that there is a significant difference in teaching reading using retelling strategy and not using retelling strategy. There is a positive contribution to the teaching of English reading comprehension by using retelling strategy in the SMAN 1 Jonngat, Praya, Central Lombok. The questionnaire covered the impact of Retelling after reading, the ability to tell after reading, the activity of reading, the power of writing after reading, and the ability to gain vocabulary after reading activities. All 25 students in the experimental class are happy and enjoy reading by using the retelling strategy. In self-report, 23 students responded in positive answers. Almost entire students are willing to continue retelling in English. They enjoy retelling the story before the audience and gaining some new words and courage. Most of them can perform Retelling as the teacher guides them, and indeed, they enjoy having new vocabularies that they did not understand earlier. 


\section{REFERENCES}

Anderson, N. J. (2005). L2 learning strategies. In E. Hinkel (Ed.), Handbook of research in second language teaching and learning (pp. 757-771). Mahwah, NJ: Lawrence Erlbaum Associates.

Anthony, R. J., Johnson, T. D., Mickelson, N. I., \& Preece, A. (1991). Evaluating literacy: A perspective for change. Portsmouth, NH: Heinemann.

Beers, K. (2000). Reading skills and strategies: Reaching reluctant readers. Elements of Literatures Series: Grades 6-12. Austin: Holt, Rinehart and Winston.

Benson, V., \& Cummins, C. (2000). The power of Retelling: Developmental steps for building comprehension. WA: The Wright Group.

Bernhardt, E. B. (1991). Reading development in a second language: Theoretical, empirical and classroom perspectives. Norwood, NJ: Ablex.

Block, C. C., \& Pressley, M. (2003). Best practices in comprehension instruction. In L. M. Morrow, L. B. Cambrell, \& M. Pressley (Eds.), Best practices in literacy instruction (pp. 111-126). NY: The Guilford Press.

Cullinan, B. E., Harwood, K. T., \& Galad, L. (1983). The reader and the story: Comprehension and response. Journal of Research and Development in Education, 16, 29-38.

Dudukovic, N., Marsh, E., \& Tversky, B. (2004). Telling a story or telling it straight: The effects of entertaining versus accurate retellings on memory. Applied Cognitive Psychology, 18, 125-143.

French, M. M. (1988). Story retelling for assessment and instruction. Perspectives forTeachers of the Hearing Impaired, 7, 20-22.

Gambrell, L. B., Koskinen, P. S., \& Kapinus, B. A. (1991). Retelling and the reading comprehension of proficient and less-proficient readers. Journal of Educational Research, 84(6), 356-362.

Gambrell, L. B., Malloy, J. A., \& Mezzoi, S. A. (2007). Evidence-based best practices for comprehensive literacy instruction. In L. B. Gambrell, L. M. Morrow, \& M. Pressley (Eds.), Best practices in literacy instruction (pp. 11-29). NY: The Guilford Press.

Gambrell, L. B., Morrow, L. M., \& Pressley, M. (2007). Best practices in literacy instruction. NY: The Guilford Press.

Gambrell, L. B., Pfeiffer, W., \& Wilson, R. (1985). The effects of Retelling upon reading comprehension and recall of text information. Journal of Educational Research, 78, 216220.

$\mathrm{Hu}, \mathrm{H}$. (1995). Bringing written Retelling into ESL, English as a second language, writing class. Journal of Developmental Education, 19(1), 12-14.

Hurley, J. (1986). Classroom techniques for teaching oral proficiency. Youngtown, $\mathrm{OH}$ : Youngtown University. (ERIC Document Reproduction Service No. ED 280 303)

Kintsch, W. (2004). The construction-integration model of text comprehension and its implications for instruction. In R. B. Ruddell, \& N. J. Unrau (Eds.), Theoretical models and processes of reading (pp. 1270-1328). Newark, DE: International Reading Association.

Koskinen, P. S., Gambrell, L. B., Kapinus, B. A., \& Heathington, B. S. (1988). Retelling: A strategy for enhancing students' reading comprehension. The Reading Teacher, 41(9), 892-896.

Leslie, L., \& Caldwell, J. (2001). Qualitative Reading Inventory-3. New York: Longman.

Marsh, E. J. (2007). Retelling is not the same as recalling: Implications for memory. Current Directions in Psychological Science, 16(1), 16-20.

Marsh, E., \& Tversky, B. (2004). Spinning the stories of our lives. Applied Cognitive Psychology, 18, 491-503. 
Marsh, E., Tversky, B., \& Hutson, M. (2005). How eyewitnesses talk about events: Implications for memory. Applied Cognitive Psychology, 19, 531-544.

McCormick, S., \& Cooper, J. O. (1991). Can SQ3R facilitate secondary learning-disabled students' literal comprehension of expository text? Three experiments. Reading Psychology: An International Quarterly, 12, 239-271.

Montague, M., Maddux, C. D., \& Dereshiwsky, M. I. (1990). Story grammar and comprehension and production of narrative prose by students with learning disabilities. Journal of Learning Disabilities, 23, 190-197.

Morrow, L. M. (1985). Retelling stories: a strategy for improving young children's comprehension, concept of story structure, and oral language complexity. The Elementary School Journal, 85, 646-661.

Morrow, L. M. (1986). Effects of structural guidance in story retelling on children's dictation of original stories. Journal of Reading Behavior, 18, 135-152.

Morrow, L. M. (1993). Using story retelling to develop comprehension. In K. Muth (Ed.), Children's comprehension of text: Research into Practice. Newark, DE: International Reading Association.

Moss, B. A. (1997). Qualitative assessment of first graders' Retelling of expository text. Reading Research and Instruction, 37(1), 1-13.

Moss, B. A. (2003). Exploring the literature of fact. New York: The Guilford Press.

Moss, B. A. (2004). Teaching expository text structures through information trade book retellings. The reading Teacher, 57(8), 710-718.

Moss, B., Leone, S., \& Dipillo, M. L. (1997). Exploring the literature of fact: Linking reading and writing through information trade books. Language Arts, 74, 418-429.

Pauk, W. (2000). Six-way paragraphs: Introductory level (3rd Ed.). Singapore: McGrawHill Education.

Pellegrini, A. D., \& Galda, L. (1982). The effects of thematic-fantasy play training on the development of children's story comprehension. American Educational Research Journal, 19, 443-54.

Pressley, M. (2002). Conclusion: Improving comprehension instruction: A path for the future. In C. C. Block, L. B. Gambrell, \& M. Pressley (Eds.), Improving comprehension instruction: Rethinking research, theory and classroom practice (pp. 385-400). CA: Jossey-Bass, A Wiley Imprint.

Richardson, J. S., \& Morgan, R. F. (2003). Reading to learn in the content areas (5th ed.). Belmont, CA: Wadsworth/ Thomson Learning.

Rose, M. C., Cundick, B. P., \& Higbee, K. L. (1984). Verbal rehearsal and visual imagery: Mnemonic aids for learning disabled children. Journal of Learning Disabilities, 16, 353-54.

Stewig, J. W. (1985). Children's literature: An impetus to composition. Houston, TX: Paper presented at Annual Meeting of the Texas Joint Council of Teachers of English. (ERIC Document Reproduction Service No. ED326899)

Taiwan Testing Center (n.d.). Retrieved September 28, 2008, from http://www.irt.org.tw/ Index.php?mod=irt-anylysis

Taylor, I. (1990). Psycholinguistics: Learning and using language. NJ: Prentice Hall. Tennessee Department of Education (2007). Retelling. Retrieved May 10, 2007, from http://www.state.tn.us/education/ci/cistandards2001/la/cicontentreading.pdf Tversky, B., \& Marsh, E. (2000). Biased retellings of events yield biased memories. Cognitive Psychology, 40, 1-38. 